\title{
Developments in breeding winter wheat for bread-baking quality in some north-western European countries
}

\section{J. Mesdag}

Foundation for Agricultural Plant Breeding, P.O. Box 117, 6700 AC Wageningen, Netherlands

Received 21 January 1985; accepted 1 July 1985

Key-words: breeding, winter wheat, bread-baking quality, kernel yield, north-western Europe, components of baking quality

\section{Summary}

In each of the north-western European countries conditions are suitable for growing wheat with good baking quality, however the appropriate varieties are to be chosen with care. For the breeder it is difficult to combine good baking quality with high yielding ability and yield stability.

Seen within periods of time, it appears that varieties with a higher score for bread-baking quality generally tend to have a lower kernel yield. But from the examples presented it can be concluded that high yield potential and good baking quality can be combined into one variety, though the result may be attained less rapidly than with breeding for yield alone.

Considering the occurrence of such examples of successful breeding, the question has been raised whether their frequency can be increased. Knowledge of components of baking quality would facilitate the choice of parental varieties and would make the breeding process more efficient. Identification of proteins of high molecular weight with electrophoresis is considered to be a tool to unravel the determinant components of quality.

\section{Introduction}

According to a definition which is at least valid for Dutch conditions, baking quality is the suitability for the preparation of a loaf with a large volume and with a light, fine and regular crumb structure. Definitions of bread-making quality in neighbouring countries may be more or less different for the main criteria, dependent on, among other things, the main type of bread used in the country concerned.

There is no doubt at all that it is possible to grow a wheat with a good baking quality in each of the north-western European countries. Fig. 1 presents a loaf baked from a breeding line with a very good baking quality, grown at a trial field in the Netherlands, and for comparison of loaf baked from a sample of the old commercial 


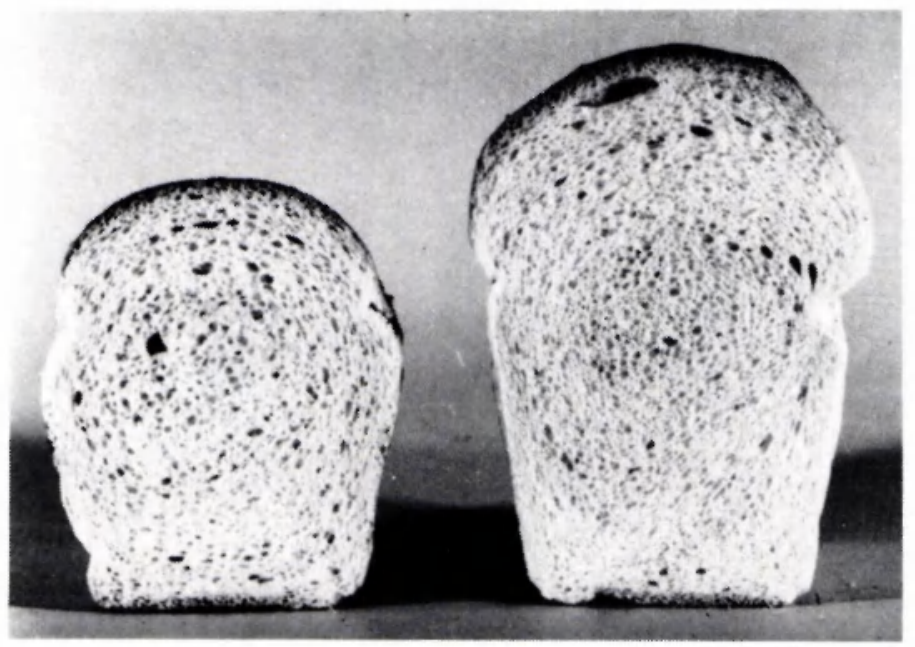

Fig. 1. A loaf baked from a sample of a breeding line with a good baking quality (at the right) and, for comparison, a loaf baked from a sample of the old commercial variety 'Orca', both grown in a trial field in the Netherlands (photo IGMB-TNO).

variety 'Orca' grown at the same field.

This observation is the basis for this survey. Further discussions are needed, however, because of the difficulties involved in the combination of good baking quality with so many other characters the wheat variety must have for practical use, such as high yielding ability and reliability of yield (winter hardiness, resistance to diseases, stiff straw, etc.).

The purpose of breeding wheat for better baking quality is:

- the creation of varieties which are more appropriate to the technological processes of milling and baking than the current varieties; or

- the creation of varieties of equal baking quality but, in comparison with the current varieties, with improved productivity and reliability of yield.

Speaking of baking quality of wheat, we have to realize that the term includes more than the characteristics which are important during the baking process itself. Baking quality in the broader sense is a complex of characteristics, involving the behaviour during the milling and dough-making processes, as well as during the baking process itself. But, on the other hand, this subdivision into three aspects of baking quality is only partially realistic, because characteristics in one category influence those in the other and conversely.

The endosperm of the wheat kernel contains the most essential element for dough-making and baking processes, namely the protein, representing about $10-$ $13 \%$. Part of the proteins, the water-insoluble proteins or gluten, have a specific function in the processes: the gluten forms a skeleton around the starch particles and the endosperm cells. This skeleton holds the carbon dioxide which is formed during the fermentation process. The better the extensibility and the elasticity of 
the gluten, the better it will hold the carbon dioxide enclosed in the dough and the more the dough will rise. When subsequently the dough is heated in the oven, the skeleton of gluten will be fixed and thereby the crumb structure and the loaf volume.

Thus the gluten plays an essential role during the dough making and baking processes. This role is determined by the amount of it and by its characteristics. It is a pity that no simple, direct tests for the gluten quality or quantity are available; therefore the quality of gluten during the dough making and baking processes has to be investigated indirectly. For this purpose many tests are available.

A very logical test to demonstrate the baking quality is of course the baking process itself. Therefore all the steps during milling, dough making and baking have to be in accordance with standardized recipes and procedures. The loaf will be judged by different criteria: the volume, the crust colour, the crumb structure and colour.

Important information with respect to the baking quality is provided by the rela-

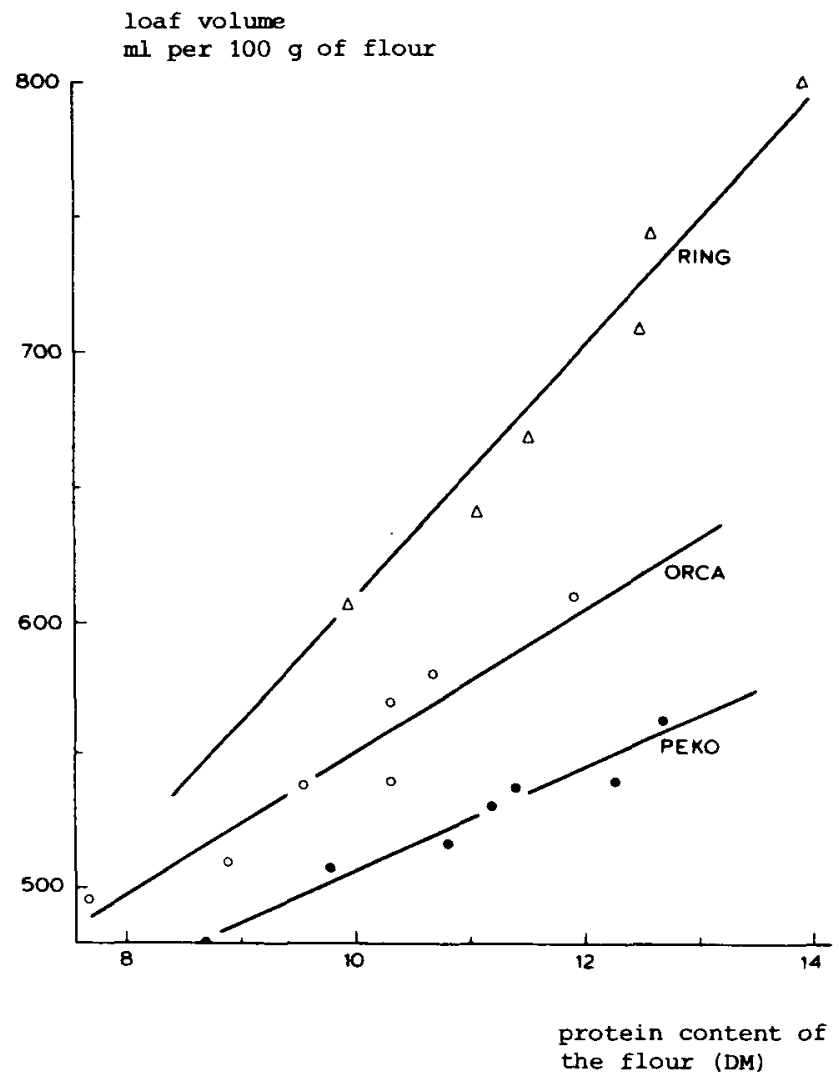

Fig. 2. The relation between loaf volume and protein content of the flour for three wheat varieties, with good, intermediate and low baking quality respectively (from: Belderok \& Meppelink, 1977). 
tion between loaf volume and protein content. This is explained in Fig. 2 (after Belderok \& Meppelink, 1977). Each of the three lines in this figure represents the relation between loaf volume and protein content for a certain variety. Samples of the Swedish spring wheat variety 'Ring' showed a larger loaf volume at a certain protein content than those of the old German variety 'Peko', while the increase in loaf volume with increasing protein content was larger for 'Ring' than for 'Peko'; thus the baking quality of the former variety is considerably better than that of the latter.

At the Institute for Cereals, Flour and Bread (IGMB) at Wageningen a micro baking test has been developed with only $10 \mathrm{~g}$ of flour. By contrast, in the standard baking test of the same institute loaves of $240 \mathrm{~g}$ of dry matter are baked. The results of the micro baking test agree fairly well with those of the standard baking procedure.

A baking test is too complicated and too expensive to be used by the breeder during the early stages of his selection programme. Therefore quite a number of indirect tests for the investigation of gluten quality were developed, of which some are of special interest for use by breeders: the Pelshenke or dough-ball test (Pelshenke, 1933a), the Zeleny sedimentation test (Zeleny, 1947), the mixograph test (Finney \& Shogren, 1972) and the SDS sedimentation test (Axford et al., 1978). These tests will not be discussed here, but an exception will be made for the Chopin extensigraph or alveograph, which has been used extensively in France, but not in many other countries. For this test a dough is made according to a specific procedure. This dough is extruded in the form of a sheet and disks are cut from this sheet. Such a disk 'is placed on a base plate and air is forced through a hole in the base plate under the dough sheet. The latter forms an expanding bubble which finally ruptures'. The pressure in the dough bubble is recorded (by the alveograph) and the area under the alveograph curve is proportional to the work of deformation (the $\mathrm{W}$ of Chopin) (Bloksma \& Hlynka, 1964).

In the next part of this survey results of breeding work for baking quality in winter wheat done in France, Great Britain, the Federal Republic of Germany and the Netherlands will be described.

\section{Baking quality in France}

The history of baking quality of winter wheat varieties in France can be traced back at least to the past century: land races with a better baking quality than others were available. An example of such a land race is the 'Blé seigle', described by Henri Vilmorin (1880) in the book 'Les meilleurs blés'. The quality of this variety was described by him as remarkably good. Incidently, this variety is one of the ancestors of several French quality wheats from the past 60 years.

Thus, in France one was aware of baking quality. An important 'quality gene pool' was available which has been used intensively and with success by the French breeders during this century. 


\section{Development of kernel yield and baking quality during the past 35 years in France}

Yield figures from official yield trials in northern and central France were summarized by Linais (1975); for the recent period additional figures have been added (Willm, 1981; Willm, 1983; Codron et al., 1984). These yield figures for five different periods between 1961 and 1983 are presented in Fig. 3. These figures show a $100 \%$ increase in yield from the variety 'Vilmorin 27 ' during the period 1951-1957 towards 'Fidel' during the period 1979-1983.

Linais (1975) ascribed half of the yield increase during the period 1951-1974 to varietal effects and the other half to cultural methods. This effect of improved management has been indicated in Fig. 3, in which for a number of varieties which were grown during more than one of the periods mentioned here, the points indicating the yield of each individual variety during the earlier and the next period are con-

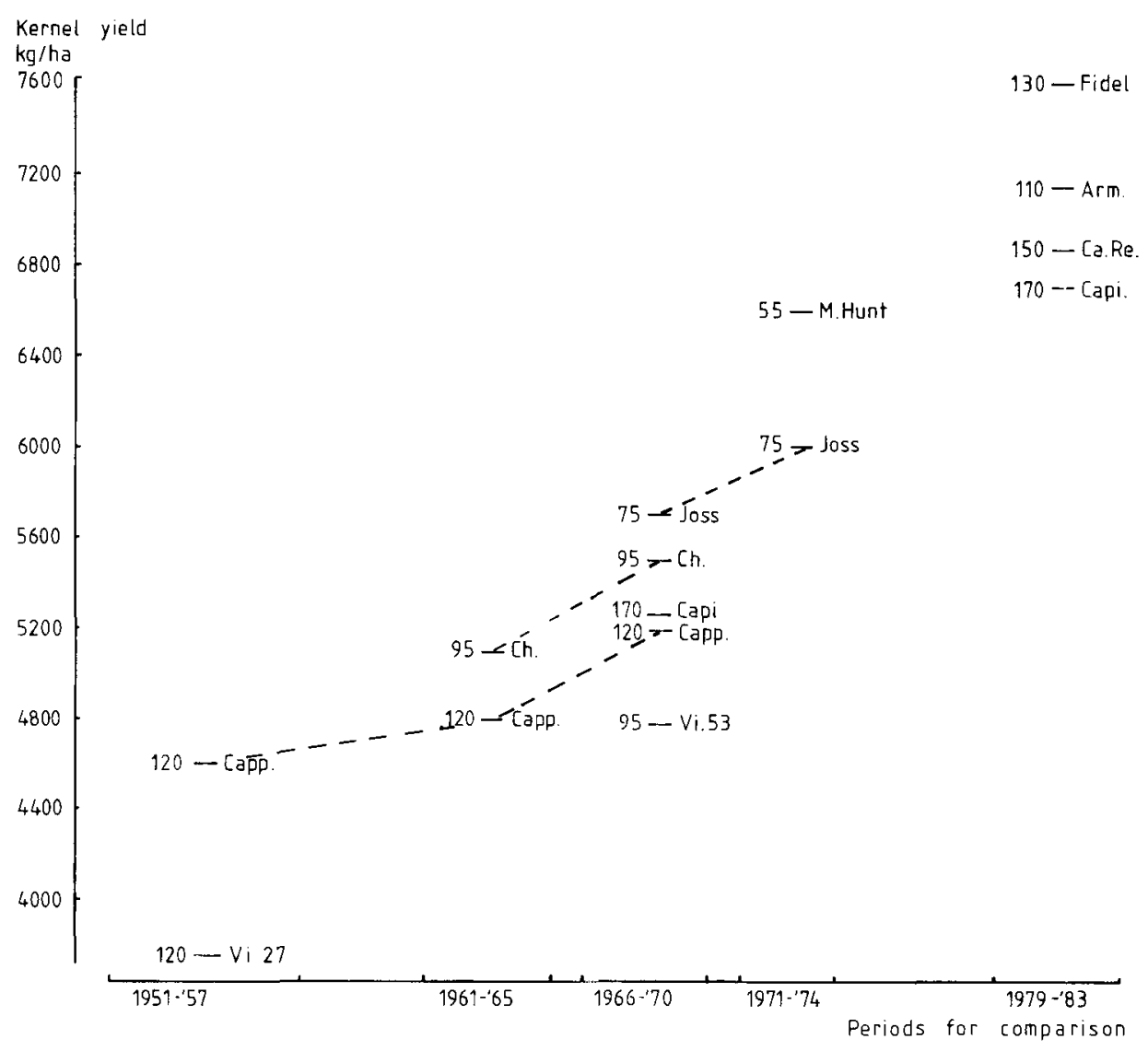

Fig. 3. Yield figures and $\mathrm{W}$ values for some main winter wheat varieties in official trials in northern and central France during the indicated periods of years between 1951 and 1983. 
nected by a dotted line. Besides, the varietal effect is also evident, as during each new periơd new and more productive varieties were grown, which were not yet available during the preceding period.

Next the development of yield during this period with that of the baking quality is compared. For this purpose also the $\mathrm{W}$ values of the different varieties (Nuret, 1955; Nuret et al., 1968; Simon, 1974; Willm, 1981) are presented in Fig. 3.

It is interesting to compare for some pairs of varieties the increase in yield and the difference in baking quality (expressed in the $\mathrm{W}$ value after Chopin). The kernel yield of 'Cappelle Desprez' during the period 1951-1957 was $21 \%$ higher than that of the older variety 'Vilmorin 27', while the W value of both varieties is 120 . This is a good example of an increase in yield through breeding, in combination with an unchanged quality.

The yield of 'Capitole' during the period 1966-1970 was (Simon, 1968) only $1 \%$ higher than that of 'Cappelle', but the $\mathrm{W}$ values differ by 50 points. This is an example of an important increase in quality for the younger variety 'Capitole', in combination with a virtually unchanged yield level.

Outstanding examples of a sharp increase in yielding ability compared with the existing varieties at the moment of their admission in France (1966 and 1973) were the varieties 'Joss' and 'Maris Huntsman', but the W values were very low, namely 75 and 55. During the following period newer varieties with a better baking quality came up with the yielding ability of 'Maris Huntsman'. Among those varieties was 'Fidel' with a $\mathrm{W}$ value of about 130 .

The variety 'Maris Huntsman', together with 'Clement' from the Netherlands, are examples of high-yielding varieties which would lead, within the European Common Market, to a new category of wheat varieties, namely those with sticky doughs, or in French 'des blés inmachinables'. The introduction of those varieties in France gave rise to the question whether it was possible to combine high yield and good baking quality into one wheat variety (Nuret, 1981). This had also been the subject of discussions in earlier years (Jonard, 1948).

A comparison of kernel yield and baking quality (expressed in the $\mathrm{W}$ value) for six main varieties and the new and more productive variety 'Joss' during the period 1966-1970 has been presented in more detail in Fig. 4a. Three main conclusions can be drawn:

- the variation in $\mathrm{W}$ value is considerable;

- varieties of low kernel yield as well as the highest-yielding varieties have a low $\mathrm{W}$ value;

- the highest-yielding varieties tend to have a lower $\mathrm{W}$ value than the varieties with a relative yield of about 100 .

Fig. $4 \mathrm{~b}$ shows the same values for nine main winter wheat varieties for the northern and the central part of France during the period 1979-1983. Here again there is a tendency for the highest-yielding varieties to have a lower $\mathrm{W}$ value, although this tendency is less clear during this period than during the period 1966-1970, owing to the presence of the highest-yielding variety ('Fidel') with the relatively high W value of 120 .

From these examples of wheat breeding in France during the 20th century, we 

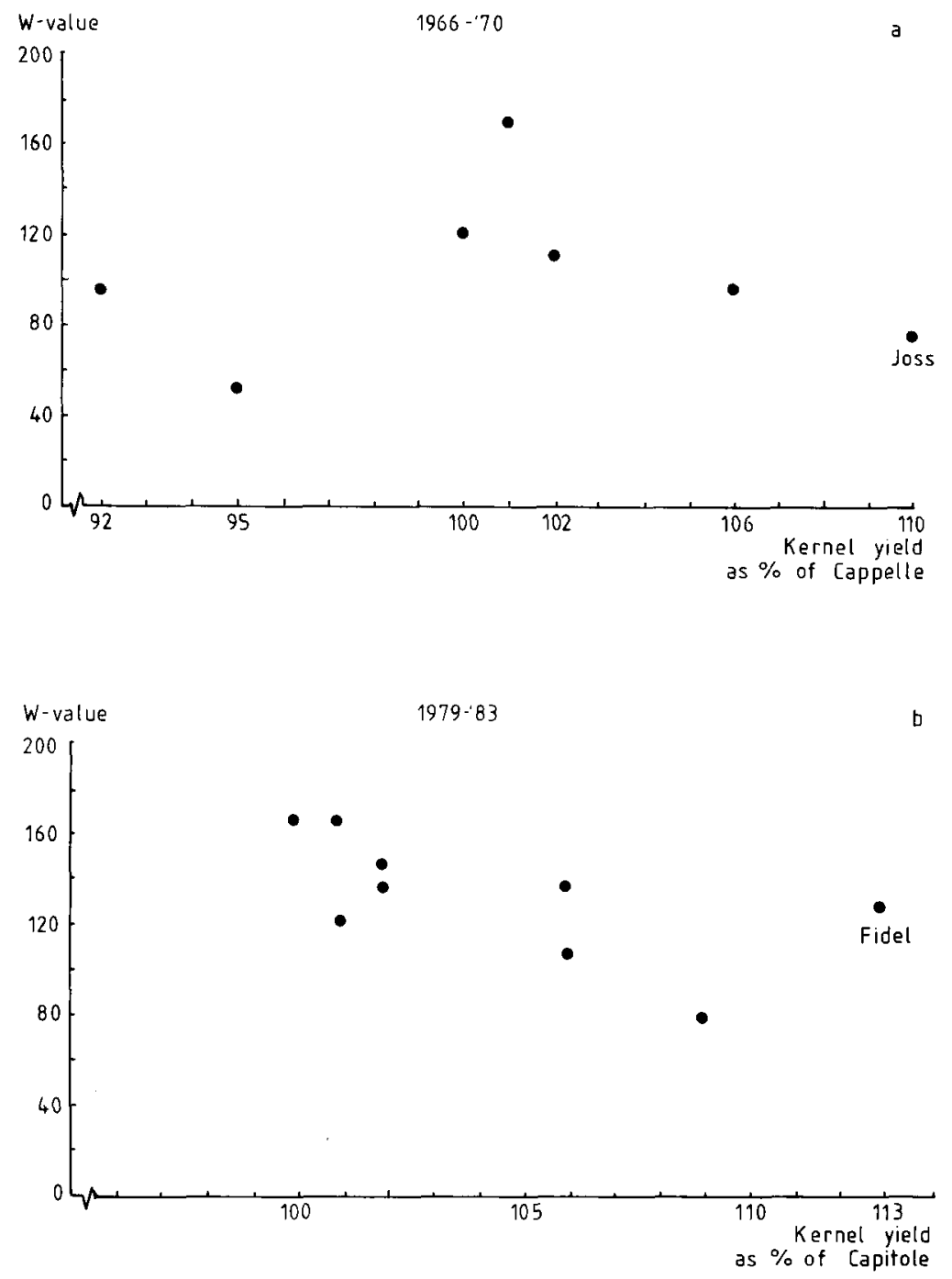

Fig. 4. Comparison of kernel yield (in relative figures) and $\mathrm{W}$ value for the main winter wheat varieties for the northern and the central parts of France:

a: the situation during the period 1966-1970;

b: the situation during the period 1979-1983.

may conclude that a high yield potential and good baking quality can be combined into one variety, though the result may be reached with a certain delay in comparison with the combination of the same yield and a lower quality level in another variety. 


\section{Breeding wheat with improved baking quality in Great Britain in the 20th century}

The situation of wheat production in England and Wales during the period from 1880 until about 1920 has been outlined by Biffen \& Engledow (1926). The homegrown wheat was of low baking quality and therefore very high percentages of imported high-quality wheat were used by the millers.

The varietal situation is characterized by the following remarks. Flour milled from one of the main varieties gave a loaf of nearly $80 \%$ of the volume generally accepted for bread making at that time and the variety with the lowest quality gave a volume of only $54 \%$. The Dutch variety 'Wilhelmina', when grown in England, could, in the words of Biffen, 'hardly be described as a bread wheat, except in the sense of the word as used by systematic botanists'.

According to Biffen and Engledow, in the beginning of this century a great deal of research was done in England and Wales to answer the question whether or not it was possible to grow wheat of better strength there. The answer to this question was positive, but the yielding capacity of such foreign wheats with good quality was lower than that of the traditional varieties.

Breeding experiments to combine the strength of certain Canadian wheats with the yielding capacity of English wheat varieties were started at the Plant Breeding Institute at Cambridge in the first decade of this century. In an early stage, namely in the $F_{3}$ or $F_{4}$, 'cultures', as Biffen called them, were compared for their quality by the chewing test. 'This test is based on the physical characteristics of the gluten when isolated by chewing some twenty or thirty grains for ten minutes or so. The starchy contents disappear ...., thus leaving a pellet of gluten in the mouth. A shrewd idea of its toughness can be formed by stretching the pellet' (Biffen \& Engledow, 1926). In this way they managed to find a combination of yield 'of the expected level at that time' (Bingham, 1962) and good quality in the offspring from a cross between the Canadian variety 'Red Fife' and the English variety 'Browick'. This variety, called 'Yeoman', was brought into cultivation in 1916. Biffen \& Engledow (1926) stated: 'The strength of Yeoman wheat is sufficient to produce a flour from which a marketable loaf can be made'. This variety found its place in British agriculture.

This policy of breeding for a combination of good baking characteristics, high yield and reliability of yield continued to be part of the breeding activities at the P.B.I. As regards the indirect tests for baking or milling quality employed in the selection procedure, the very simple test which was used about 1910 has been replaced by modern ones. In 1935 'Holdfast', derived from the cross of 'Yeoman' with the Canadian quality wheat 'White Fife', was released. 'Holdfast' and, through it, 'Yeoman' played an essential role in the breeding programme performed at the P.B.I. during the past 30 years (Lupton, 1982). Private breeders in England carried out similar work towards the same end, using Scandinavian or French varieties as well as 'Yeoman' as sources of baking quality. 
Improvement of kernel yield and baking quality of winter wheat varieties during the past 30 years in England and Wales

Data for kernel yield and the bread making scores of 19 varieties were compiled (Bullen et al., 1955; Reiss, 1958; Proctor \& Mann, 1961; Fiddian, 1967a,b, 1968; Mann, 1979, 1983). Each of these 19 varieties enjoyed a certain popularity in England and Wales for a shorter or a longer time (Fig. 5).

A steady increase in kernel yield is apparent: from $3980 \mathrm{~kg} / \mathrm{ha}$ during the period $1949-1952$ to $6770 \mathrm{~kg} / \mathrm{ha}$ during the years $1978-1982$, which means a yield increase of $70 \%$.

During some periods a rather quick change in the pattern of winter wheat varieties took place, during other periods this pattern was rather stable, for example during the period from 1957 until 1970, when a considerable part of the winter wheat area was sown with the French variety 'Cappelle Desprez'.

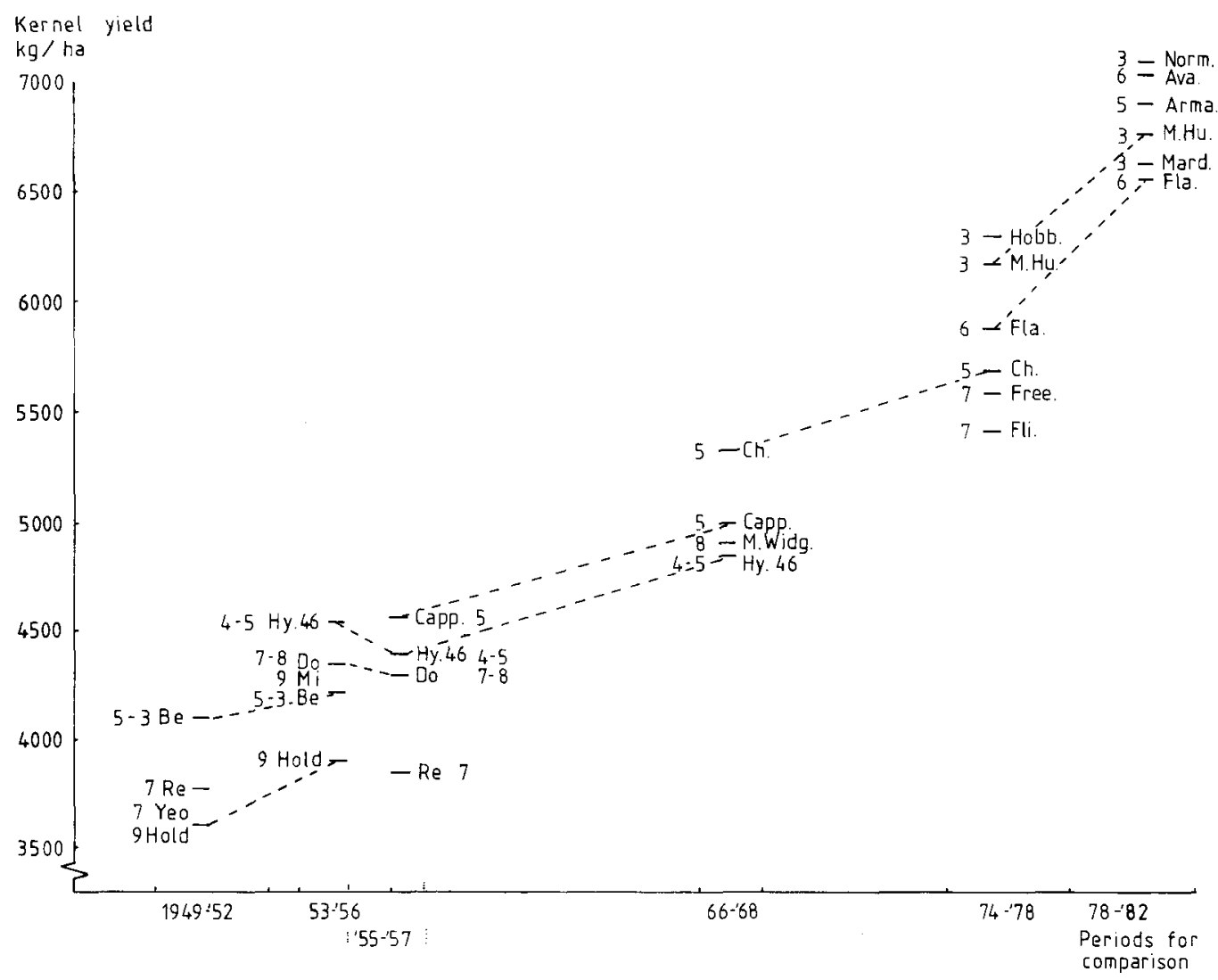

Fig. 5. Yield figures and scores for bread-making quality for some main winter wheat varieties in official trials in England and Wales during the indicated periods of years between 1949 and 1982. 
The increase in kernel yield is partly due to varietal effects and partly to improved cultural methods; the varietal effect in the yield increase has been estimated at $50 \%$ of the total effect (Silvey, 1978, for the period 1947-1975).

For some varieties which were grown during more than one of the periods mentioned, the effect of improved cultural methods has been indicated in Fig. 5; for such varieties the values indicating the yield during the first and the next period respectively are connected by a dotted line. Generally these lines point out an increase in yield. Besides this effect of cultural methods on kernel yield, the varietal
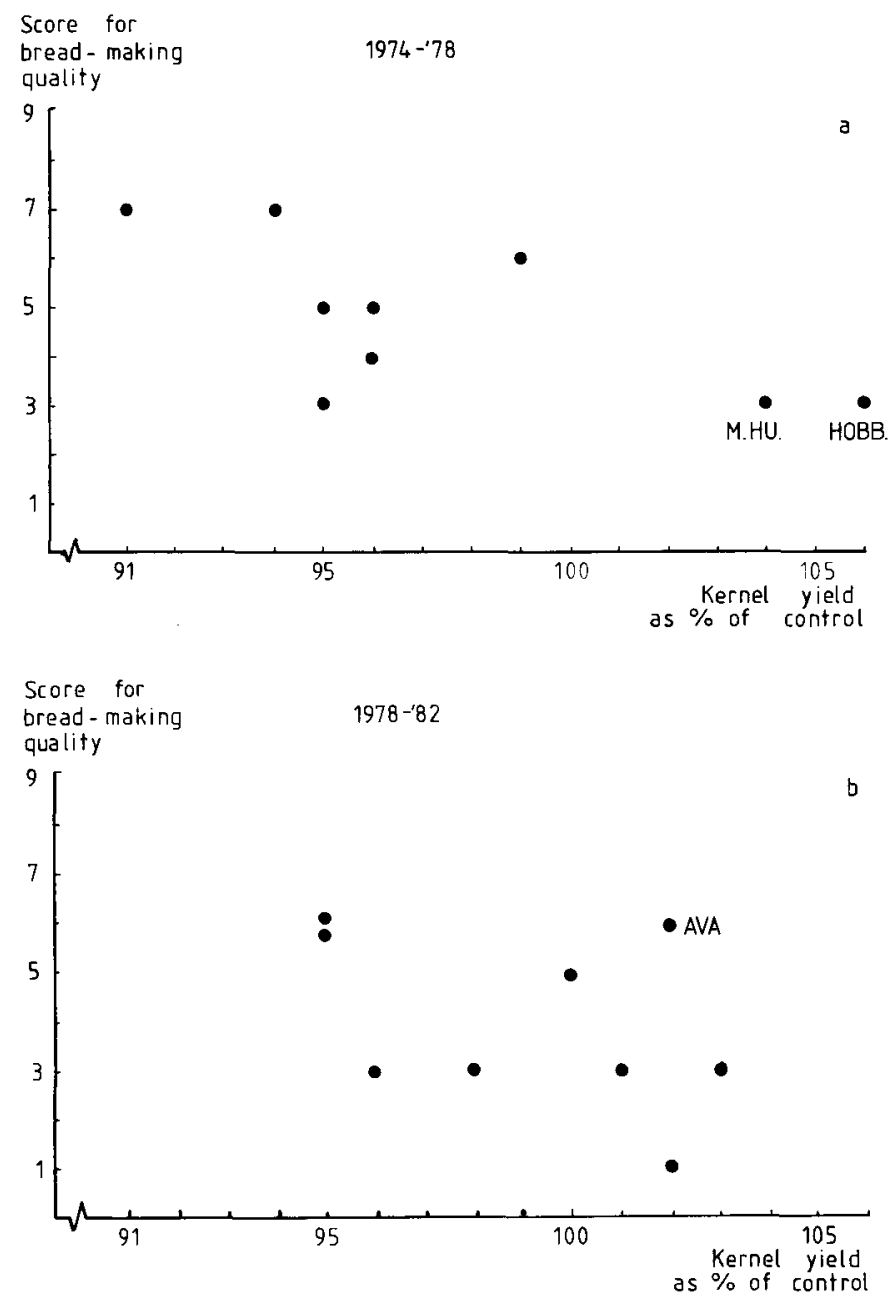

Fig. 6. Comparison of kernel yield (in relative figures) and score for bread-making quality for the main winter wheat varieties in England and Wales:

a: the situation during the period 1974-1978;

b: the situation during the period 1978-1982. 
effect also is evident, as during nearly each new period one or more new and more productive varieties have been grown which were not yet available during the former period.

Moreover the score for bread-making quality for each of the varieties has been added to Fig. 5. This score varies from 1 to 9; a high score means that the variety has an excellent baking quality (according to British standards) (Anon., 1953, 1956, $1962,1966,1975,1978$ ).

Looking at the results presented for a certain period, a variety with a higher score for bread-making quality generally has a relatively low kernel yield. Favourable exceptions are the varieties 'Dominator' and 'Milfast' during the period 1953-1956 and 'Avalon' during the last period (1978-1982).

The combination into one variety of good baking quality and a certain yield level which is below that of other varieties has often been taken over towards the next period, when in a new variety the same or a higher quality level was combined with a higher yield potential. Some examples are 'Dominator' and 'Milfast' during the period 1953-1956 in comparison with 'Bersee' during the preceding period; or 'Flinor' and 'M. Freeman' during the period 1974-1978 compared with 'Cappelle Desprez' in earlier periods, and 'Avalon' during the last period, compared with 'M. Huntsman' during the same and the preceding period.

A comparison of kernel yield and baking quality for nine main varieties grown during the period 1974-1978 has been presented in more detail in Fig. 6a. From this figure it is clear that the highest-yielding varieties ('Maris Huntsman' and 'Hobbit') have a low score for bread-making quality, and that the varieties with breadmaking scores of 6 or 7 yielded less.

In Fig. $6 \mathrm{~b}$ the same values have been indicated for nine main varieties grown during the period 1978-1982. Now the situation has changed, as among the four highest yielding varieties, one variety ('Avalon') has a breadmaking score of 6 .

The figures presented here illustrate the statement of Pushman \& Bingham (1975): 'The yield of quality varieties lags behind varieties bred for yield alone, mainly because selection for the many components of quality is an additional complication which slows down the work and greatly restricts the genetic variability that can be exploited in breeding for other characters.'

Nevertheless during the past 30 years, and even during the first half century, in England very good results have been achieved in combining good baking quality and higher yield into new varieties.

\section{Development of wheat quality during the past 100 years in pre-war Germany and the German Federal Republic}

The baking quality of the land races of wheat grown in Germany until about 1880 was investigated by Pelshenke (1954). Quite a number of those land races were kept in collections, so that they could be sown in trials at Halle in the 1930s. Material harvested from these trials was tested for its baking quality and it appeared that the gluten quality of those land races was essentially better than that of the current varieties in Germany. In the opinion of Hoeser et al. (1979) one should not general- 
ize by saying that all these land races had a good baking quality, "but that many of them had a quality level which was satisfactory for the demands at that time, which were essentially more modest than nowadays'.

During the 1920 s breeders in Germany were already active in improving yield, reliability of yield and also the baking quality. These activities were improved, when rather simple methods were developed to test quality characteristics of small wheat samples. These methods offered possibilities to select for quality characteristics in an early stage of the selection procedure.

It is interesting to mention that in Germany during the 1930s besides wheat varieties of low baking quality and with, for that period, a high yield, wheat varieties of good (A or B) quality were also grown (Pelshenke, 1933). But in this respect there were great differences between the various parts of Germany: in Bavaria $40 \%$ of the varieties had A or B quality, in contrast to Northern Germany where only $4 \%$ of quality wheats were grown (Pelshenke, 1934).

Already in those years, there were discussions about the extent to which it would be possible to combine high yield, reliability of yield and good baking quality into a wheat variety (Pelshenke, 1934; Vettel \& Pelshenke, 1934). Investigations of Vettel and Pelshenke contradicted the common opinion that this would not be possible.

\section{The combination of higher yield and better baking quality in winter wheat varieties during the past 50 years in pre-war Germany and in the German Federal Republic}

A good impression of the precarious success of breeding for improved yield and good baking quality during a longer period is obtained from investigations of Hoeser et al. (1979). They tested nine German winter wheat varieties, which were important during certain periods between 1921 and 1975, in yield trials and the baking quality of the harvested samples was investigated. The kernel yield (in $\mathrm{kg} / \mathrm{ha}$ ) and the loaf volume (in relative figures) are presented in Fig. 7. Along the horizontal axis the varieties are arranged according to the year of release.

The variety 'Carsten V' was released in 1921. It was an important variety in Germany (and the Netherlands), but the baking quality was low. The variety 'Tassilo', which was released in 1930, was a product of deliberate breeding for yield and quality; it was selected from a cross between a German land race ('Traublinger Landweizen') and a French wheat ('Arras'). The loaf volume is considerably better than that of 'Carsen V', but its yield is $9 \%$ lower. About ten years later the varieties 'Walthari' and 'Taca' were released; they gave the same yield as 'Carsten V', while the former has the same loaf volume as 'Tassilo'. A considerable improvement of the productivity was shown by the variety 'Heine VII', which was released in 1950 , but the baking quality was as low as that of 'Carsten V'.

A combination of the yield level of 'Heine VII' and an improved baking quality was found during the 1960s in the varieties 'Schernauer' and 'Jubilar'.

Again a great improvement in yield was achieved in the varieties 'Caribo' and 'Disponent' (released in 1968 and 1975 respectively), the former with a loaf volume like that of 'Schernauer' and 'Jubilar', but the latter with $8 \%$ more loaf volume than 'Tassilo'. 'Disponent' is now one of the main varieties in the German Federal 


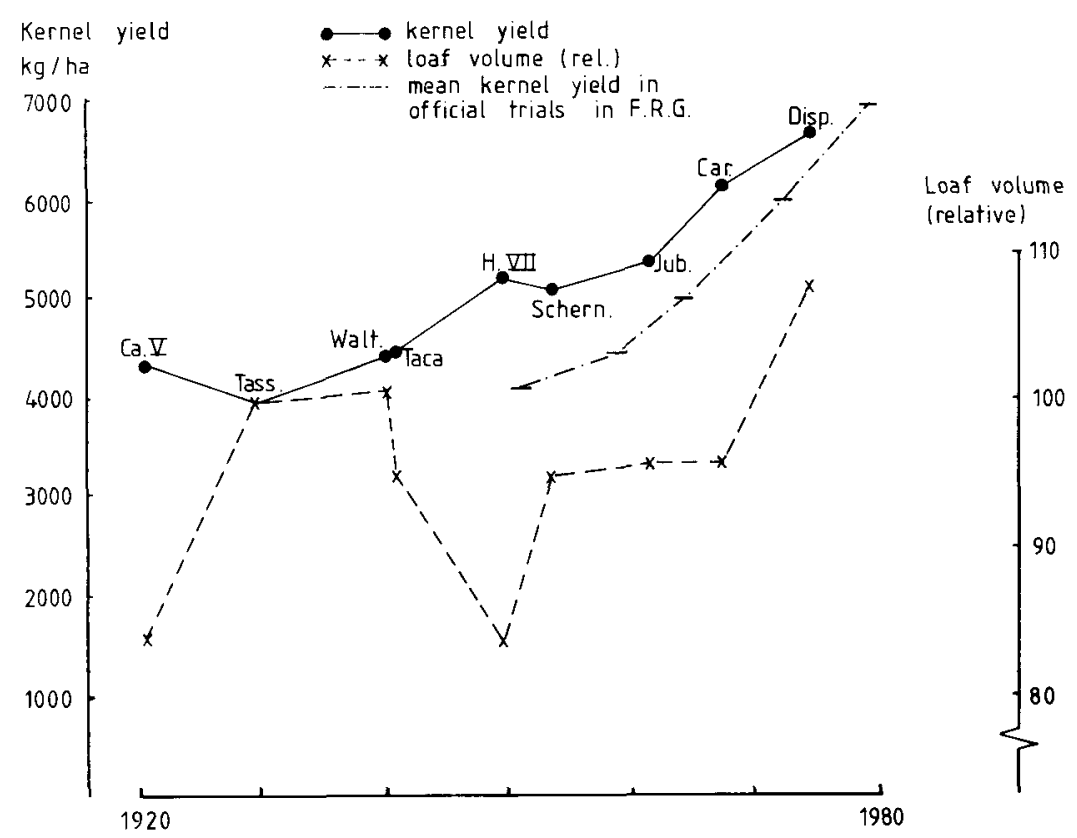

Fig. 7. Kernel yield and loaf volume (relative to 'Tassilo') for nine German winter wheat varietics released between 1920 and 1975 (after: Hoeser et al., 1979) and, for comparison, the mean kernel yield of winter wheat in official trials in the German Federal Republic (after: Schuster et al., 1982).

Republic.

It is interesting to verify whether the yield level of the varieties which were chosen by Hoeser et al. (1979) was representative of the yield level of the German wheat varieties in general during this period. For this purpose a yield figure for each of five shorter periods has been presented in Fig. 7. These figures are taken from Schuster et al. (1982), who presented the yield figures of the official trials with winter wheat in the Federal Republic.

It is evident that the yield level of the official trials in the Federal Republic for the period 1951-1981 is lower than that of the yield trial of Hoeser et al. for the varieties which were released during this same period. But the trends of the yield increase for both series of varieties are in good agreement. Thus one may conclude that the yield increase for the varieties in the trial of Hoeser et al. is a good indication of the yield increase of winter wheat in the German Federal Republic.

A survey of the actual situation for the combination of kernel yield and baking quality in winter wheat varieties in the Federal Republic has been presented in Fig.

8 . From this figure it may be concluded that:

- a negative tendency between yield and baking quality is apparent, although this tendency is not valid for the lowest classes of the quality classification;

- within most yield levels there is a rather wide variation in quality classes;

- within the middle quality classes there is a rather wide variation in yield levels.

Neth. J. agric. Sci. 33 (1985) 


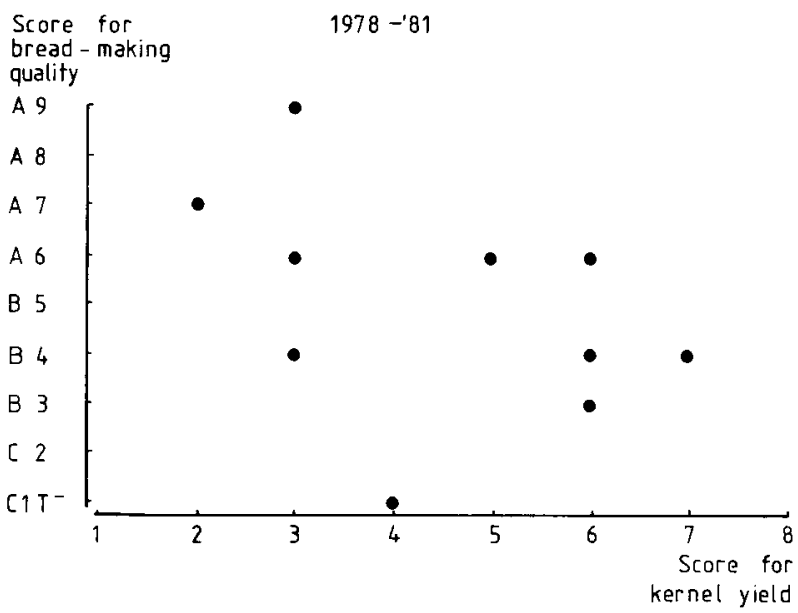

Fig. 8. Comparison of the scores for bread-making quality and kernel yield (according to the Official List of Varieties) for 10 main winter wheat varieties in the German Federal Republic during the period 1978 1981.

\section{Breeding research on baking quality in the Netherlands in the present century}

On the baking quality of wheat varieties bred in the Netherlands during the first thirty years of the 20 th century little is worth mentioning.

The raw material for the production of flour for bread making was then mainly imported from North America. Thus from the side of the milling industry no stimulant could be expected to improve the baking quality of home-grown wheat. During that period several main wheat varieties were bred in the Netherlands (such as 'Wilhelmina' and 'Juliana'), but no attention was paid to the baking quality of these varieties.

Soon after the beginning of the economic depression in 1929 this situation changed. Governmental measures were taken with the aim to protect the wheat market in the Netherlands. One of these measures was to start research into the possibility of growing wheat varieties with better baking quality. It was in this research project that Dr Feekes had a major input from 1934 to 1938. This project remained restricted to an inventory of methods and varieties; breeding work for varieties with better baking quality was not started at that time (Feekes, 1942).

In the 1950s again there was a need to stimulate research in cereals and therefore in 1950 a foundation was formed, which in 1955 was changed into the well-known Foundation Netherlands Grain Centre (NGC). Dr Feekes fulfilled a very stimulating role as President of the NGC, together with Dr Broekhuizen as Secretary.

Among other things, the NGC was intensively occupied in improving baking quality by stimulating research on methods, from which, for example, the microbaking test was developed at the IGMB (Belderok et al., 1960), and stimulating 
breeding research by giving financial support to the Foundation for Agricultural Plant Breeding (SVP). Due to this financial support the breeding research in winter and spring wheat could be extended. The aim of these programmes was to release material, after adaptation by the SVP, to the Dutch breeding firms for further development.

During the past 30 years the Dutch breeding firms have given much attention to baking quality, but little has been published about these activities. Therefore, in this report some results are presented which have been attained at the SVP.

In the SVP programme, varieties with good baking quality from different parts of the world, such as Scandinavia, Germany, France, Russia and North America, have been crossed with adapted, more productive varieties. In the offspring of these crosses lines have been selected for yield and baking quality. Subsequently the most promising lines have been crossed again with other lines from this programme or with varieties, whereupon selection followed again. Besides baking quality and kernel yield some other characteristics were taken into consideration, such as winter hardiness, straw length and disease resistance. This survey will be restricted to quality and yield.

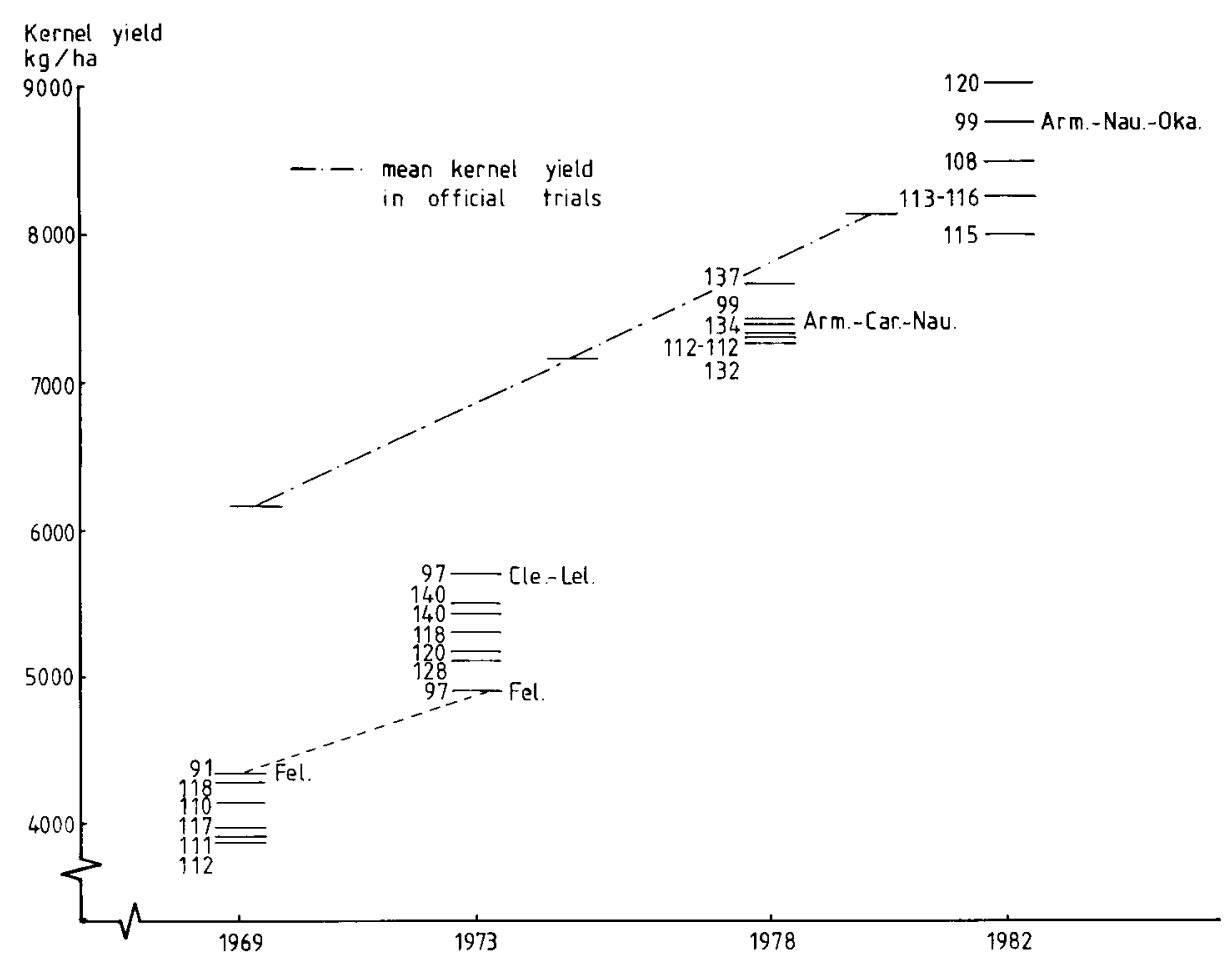

Fig. 9. Kernel yield and loaf volume (in relative figures) for standard varieties of winter wheat and for five breeding lines from the SVP programme in each of four given years between 1969 and 1982, and, for comparison, the mean kernel yield in official trials during three different periods. 
A survey of kernel yield and loaf volume of the best lines which were available in various years from the programme at the SVP is presented in Fig. 9. In addition the mean yield in official winter wheat variety trials on clay soils in the central part of the Netherlands during three succeeding periods of five years has been indicated in Fig. 9.

When details of Fig. 9 are disregarded, some general remarks can be made:

- in each of the succeeding years, the kernel yield was higher than in the preceding year;

- the mean kernel yield in the official trials in 1969 and 1973 was considerably higher than in the SVP trials, although they were situated in the same environment;

- in 1978 the yield level in the SVP trial approached that in the official trials and in 1982 the levels were the same.

Next the results of the single years will be examined. In 1969 the standard variety 'Felix' yielded better than each of the five lines. In order to compare yield and quality, in Fig. 9, the loaf volume of each genotype has been added. These loaf volumes are relative to the mean volume of four standard varieties which were sown in the same trial. In 1969 the loaf volume of 'Felix' was $91 \%$ and that of the SVP lines varied from 110 to $118 \%$.

In 1973 five other lines were compared with 'Clement' and 'Lely', but also with 'Felix'. Each of the lines produced less than 'Lely' or 'Clement', but more than 'Felix'. The mean loaf volume of 'Clement' and 'Lely' and also that of 'Felix' was $97 \%$. The loaf volumes of the lines were considerably better, and varied from 118 to $140 \%$.

A comparison of the results in 1973 with those of 1969 shows that the lines under trial in 1973 were more productive than 'Felix' and that they were even better in baking quality than those in 1969 .

In 1978 again other lines were under trial which were compared with the standard varieties 'Arminda', 'Caribo' and 'Nautica'. The mean yield of these standard varieties was $7400 \mathrm{~kg} / \mathrm{ha}$; one of the lines yielded slightly better and four lines slightly less. The mean loaf volume of the three standard varieties was $99 \%$ and for the five lines it varied from 112 to $137 \%$.

In 1982 the mean kernel yield of the standard varieties 'Arminda', 'Nautica' and 'Okapi' was $8700 \mathrm{~kg} / \mathrm{ha}$ and the mean loaf volume was $99 \%$. One line yielded slightly better and four lines gave kernel yields between 91 and $97 \%$ of the mean of the standard varieties. The loaf volume of the lines varied from 108 to $120 \%$.

It may be mentioned here that an increase in the loaf volume by $15-20 \%$ will be of vital importance for the milling industry.

The conclusion from the preceding figures is that the combination of a nearly normal yielding ability and an improved baking quality is apparent in the newest lines from the SVP. The question whether there are other features which are below a level which is needed in practive was investigated by the Dutch private breeding firms, after this material had been made available to them. 


\section{Concluding remarks}

In the introduction the fact is mentioned that it is possible to grow a wheat with a good baking quality in each of the north-western European countries, but that discussion is needed on the subject of the combination of good baking quality and normal yield.

In the preceding surveys a number of examples of winter wheat varieties with a combination of high yield and good baking quality has been given for each country.

Thus the subject of discussion should be changed from the question whether it is possible to the question whether the frequency of such varieties can be improved.

In my opinion, the frequency can be increased when the parent varieties to be used in a breeding programme can be chosen more efficiently. The choice of parent varieties cannot be optimal at this moment, as the breeder has only information on the resultant of a quality test, but not on the components of it. Information on these components could be very useful for the interpretation of the resultant. This can be explained with the following simplified examples. Consider there are three varieties:

Variety A: with a loaf volume of $500 \mathrm{~cm}^{3}$, which is the resultant of the quality components 1, 2, 3 and 4;

Variety B: with the same loaf volume and the same quality components $1,2,3$ and 4

Variety C: with the same loaf volume, which is the resultant of the quality components 5 and 6.

From a cross between the varieties $\mathrm{A}$ and $\mathrm{B}$, which have the same quality components, no improvement of the quality may be expected, but without this additional information on the components, the breeder could not know this, and he would make a cross $\mathrm{A} \times \mathrm{B}$.

In a recombination of the components $1,2,3,4$ from variety $A$ and 5 and 6 from variety $C$, an improved loaf volume may be expected, and this is what the breeder is looking for. Up to this moment the breeder will only have information on the value of combinations of varieties after examination of the offspring. It is on this specific subject of the parental choice, that we may expect an improvement of the procedure. The following expatiation may explain this.

In recent years a number of research groups in the world has investigated endosperm proteins of wheat in a very thorough way. One approach was to divide the endosperm protein into different fractions. One of those fractions, called the gel protein, drew special attention because of the fact that a correlation was found between the amount of these proteins of high molecular weight and bread-making quality.

A second step was to investigate the composition of the gel protein (Payne et al., 1981; Moonen et al., 1982). After special chemical treatments, the proteins are subjected to electrophoresis, viz: the proteins are made visible after staining in characteristic patterns of bands according to their molecular weight.

Comparison of the electrophoretic pattern of a number of wheat varieties with a broad variation in baking quality yielded a correlation between some specific bands 
and loaf volume.

A considerable number of protein bands has been detected but, up to now, only a few of them have been identified to be related with loaf volume. When more bands, either positively of negatively, related to baking quality have been identified, crosses can be restricted to varieties with complementary banding patterns.

Thus, breeding for baking quality can be done more efficiently and the lag in yield between 'quality wheats' and 'non-quality wheats' can be closed more rapidly than it would be otherwise.

\section{Acknowledgements}

The author wishes to thank Dr B. Belderok, Dr A. G. Balkema-Boomstra and Dr Th. Kramer for critical comments on the manuscript.

\section{References}

Anonymous, 1953. Varieties of winter wheats. Farmers Leaflet No 8. National Institute of Agricultural Botany, Cambridge.

Anonymous, 1956. Varieties of winter wheats. Farmers Leaflet No 8. National Institute of Agricultural Botany, Cambridge.

Anonymous, 1962. Varieties of winter wheats. Farmers Leaflet No 8. National Institute of Agricultural Botany, Cambridge.

Anonymous, 1966. Varieties of winter wheats. Farmers Leaflet No 8. National Institute of Agricultural Botany, Cambridge.

Anonymous, 1975. Recommended varieties of cereals. Farmers Leaflet No 8. National Institute of Agricultural Botany, Cambridge.

Anonymous, 1978. Recommended varieties of cereals. Farmers Leaflet No 8. National Institute of Agricultural Botany, Cambridge.

Axford, D. W. E., E. E. McDermott \& D. G. Redman, 1978. Small-scale tests of breadmaking quality. Milling Feed and Fertilizer 66(5):18.

Belderok, B., E. K. Meppelink \& D. de Ruiter, 1960. Methoden ter bepaling van de bakkwaliteit van kleine monsters tarwe. Stichting Nederlands Graan-Centrum, Wageningen, $48 \mathrm{pp}$.

Belderok, B. \& E. K. Meppelink, 1977. De bakkwaliteit van tarwe en wat daarmee in verband staat. Landbouwkundig Tijdschrift 89: 424-429.

Biffen, R. H. \& F. L. Engledow, 1926. Wheat breeding investigations at the Plant Breeding Institute, Cambridge. Research Monograph No 4. Ministry of Agriculture and Fisheries.

Bingham, J., 1962. The contribution of plant breeding to grain quality in wheat. In: Recent advances in processing cereals, Monograph 16. Society Chemical Industry, London: 34-54.

Bloksma, A. H. \& J. Hlynka, 1964. Basic considerations of dough properties. In: J. Hlynka, Wheat chemistry and technology. American Association of Cereal Chemists, Inc., St. Paul, Minnesota, 603 pp.

Bullen, E. R., C. V. Dadd \& W. E. H. Fiddian, 1955. Trials of winter wheat varieties: 1949-1952. Journal of the National Institute of Agricultural Botany 7: 244-269.

Codron, Dubost, Feyt, Laroche, Longchamp, Maumené, Mathieu \& Senechal, 1984. Variétés de céréales d'hiver - essais 1983. Perspectives Agricoles No. 82: 15-78.

Feekes, W., 1942. De tarwe en haar milieu. Verslagen van de Technische Tarwe Commissie XVII. Hoitsema, Groningen, p. 523-888.

Fiddian, W. E. H., 1967a. Wheat, barley and oat varieties completing primary trials in 1966. Journal of the National Institute of Agricultural Botany 11:1-27.

Fiddian, W. E. H., 1967b. Wheat, barley and oat varieties completing primary trials in 1967. Journal of the National Institute of Agricultural Botany 11:28-33. 
Fiddian, W. E. H., 1968. Wheat, barley and oat varieties completing primary trials in 1968. Journal of the National Institute of Agricultural Botany 12:253-284.

Finney, K. F. \& M. D. Shogren, 1972. A tengram mixograph for determining and predicting functional properties of wheat flours. Bakers' Digest 46(2): 32-35, 38-42, 77.

Hoeser, K., K. Wenisch \& K. Oppitz, 1979. Ergebnisse vergleichender Untersuchungen neuer Winterweizensorten mit Sorten aus dem Anfängen der Qualitätszüchtung. In: Bericht über die Getreide-Tagung. Granum-Verlag, Detmold, 123 pp.

Jonard, P., 1948. Influence du milieu et de la variété sur la qualité des blés, possibilités d'amélioration. Bulletin des Anciens Elèves de l'École Française de Meunerie No 104: 45-51.

Linais, B., 1975. Les variétés actuelles de blé tendre d'hiver. Techniques nouvelles de production de blé. Journée National d'Information. Institut Techniques des Céréales et des Fourrages, Paris, p. 87118.

Lupton, F. G. H., 1982. Recent advances in cereal breeding. Netherlands Journal of Agricultural Science 30: 11-24.

Mann, G. C., 1979. Wheat, barley and oat varieties completing primary trials in 1978. Journal of the $\mathrm{Na}$ tional Institute of Agricultural Botany 15: 117-134.

Mann, G. C., 1983. Wheat, barley and oat varieties completing primary trials in 1982. Journal of the National Institute of Agricultural Botany 16: 311-339.

Moonen, J. H. E., A. Scheepstra \& A. Graveland, 1982. Use of the SDS-sedimentation test and SDSpolyacrylamidegel electrophoresis for screening breeders samples of wheat for bread-making quality. Euphytica 31: 677-690.

Nuret, H., 1955. Tableau des principales variétés des blés français classés d'après leurs force boulangère. Bulletin des Anciens Elèves École Française de Meunerie No 146: 79-80.

Nuret, H., 1981. Discussion. In Y. Beaux, Blé tendre: les variétés de demain. Industries des Céréales No 9: 5-10.

Nuret, H., J. Sarazin \& R. Berrier, 1968. La force boulangère des blés français. Bulletin des Anciens Elèves École Française de Meunerie No 223: 25-35.

Payne, P. J., K. G. Corfield, L. M. Holt \& J. A. Blackman, 1981. Correlations between the inheritance of certain high molecular weight subunits of glutenin and bread-making quality in progenies of six crosses of bread wheat. Journal of the Science of Food and Agriculture 32: 51-60.

Pelshenke, P., 1933a. A short method for the determination of gluten quality of wheat. Cereal Chemistry 10: 90-96.

Pelshenke, P., 1933b. Weizen und Weizenmehlqualität in Deutschland. Kühn-Archiv 38: 84-95.

Pelshenke, P., 1934. Qualitätszüchtung bei Weizen. Der Züchter 6: 169-172.

Pelshenke, P., 1954. Über die Notwendigkeit und über die Zuchtziele in der Weizenqualitätszüchtung vom Standpunkt der Müllerei und Bäckerei. Bericht über die Tagung in Detmold am 9-10 Februar 1954: 33-45. Arbeitsgemeinschaft Getreideforschung E.V., Detmold.

Proctor, J. M. \& G. C. Mann, 1961. N.A.A.S./N.I.A.B. trials of winter wheat varieties 1955-57. Journal of the National Institute of Agricultural Botany 9: 4-24.

Pushman, Fiona M. \& J. Bingham, 1975. A reappraisal of the Pelshenke test as a screening technique in the breeding of bread-making wheats for the United Kingdom. Journal of Agricultural Science, Cambridge, 85: 221-231.

Reiss, B. C. R., 1958. Winter wheat variety trials, 1952-56. Journal of the National Institute of Agricultural Botany 8: 271-284.

Schuster, W., W. Schreiner, H. Leonhäuser \& K.-H. Zschoche, 1982. Über die Ertragssteigerung bei einigen Kulturpflanzen in den letzten 30 Jahren in der Bundesrepublik Deutschland. Zeitschrift für Acker- und Pflanzenbau 151: 368-387.

Silvey, V., 1978. The contribution of new varieties to increasing cereal yield in England and Wales. Journal of the National Institute of Agricultural Botany 14: 367-384.

Simon, M., 1968. Généralités sur les variétés de blé tendre en France. Bulletin des Anciens Elèves de l'École Française de Meunerie No 223: 13-22.

Simon, M., 1974. Catalogues et variétés de blé tendre. Bulletin des Anciens Elèves de l'École Française de Meunerie No 259: 14-28.

Vettel, F. \& P. Pelshenke, 1934. Können wir ertragreiche Qualitätsweizen züchten? Der Züchter 6: 193199. 


\section{J. MESDAG}

Vilmorin, H., 1880. Les meilleurs blés. Vilmorin-Andrieux et Cie, Paris, 175 pp.

Willm, Cl., 1981. Blés tendres de la récolte 1981. Industries des Céréales No 14: 13-22.

Willm, $\mathrm{Cl}$, 1983. Blés tendres de meunerie de la récolte 1983. Industries des Céréales No 26: 9-17.

Zeleny, L., 1947. A simple sedimentation test for estimating the bread-baking and gluten qualities of wheat flour. Cereal Chemistry 24: 465-475. 